\title{
PASAR PERSAINGAN SEMPURNA
}

Makalah Ini Disusun Untuk Memenuhi Tugas Pada Mata Kuliah Ekonomi Mikro Syariah

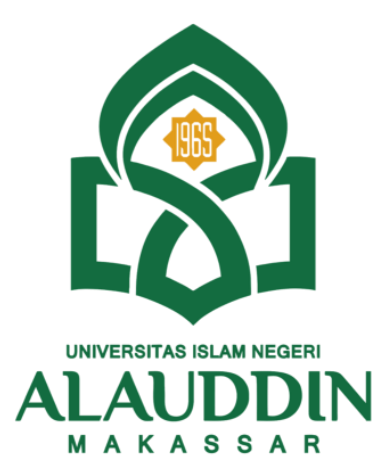

Disusn Oleh:

KELOMPOK 8

\begin{tabular}{ll} 
Miftahul Jannah & 90500120098 \\
\hline Nurfadillah & 90500120087 \\
\hline Ayu Puspitsari & 90500120093 \\
\hline Asrari & 90500120124
\end{tabular}

PERBANKAN SYARIAH

FAKULTAS EKONOMI DAN BISNIS ISLAM

UNIVERSITAS ISLAM NEGERI ALAUDDIN MAKASSAR

TAHUN 2021 


\section{KATA PENGANTAR}

Puji syukur penulis panjatkan kepada Allah swt karena berkat karunia-Nya sehingga penulis dapat menyelesaikan makalah ini yang berjudul Pasar Persaingan Sempurna dengan tepat waktu.

Makalah ini ditulis dengan tujuan untuk menambah pengetahuan bagi penulis pada khususnya dan bagi para pembaca pada umumnya. Selain itu ditujukan untuk memenuhi tugas pada mata kuliah Ekonomi Mikro Syariah.

Penulis mengucapkan terima kasih kepada Bapak Samsul, SAB.,MA. selaku dosen pada mata kuliah Ekonomi Mikro Syariah yang telah memberikan tugas ini serta membimbing kami dalam penulisan makalah ini.

Penulis menyadari bahwa dalam penulisan makalah ini masih terdapat banyak sekali kekurangan. Oleh karena itu, penulis mengarapkan kritik dan saran yang membangun demi kesempurnaan makalah ini.

Gowa, 31 Oktober 2021

Penulis 


\section{DAFTAR ISI}

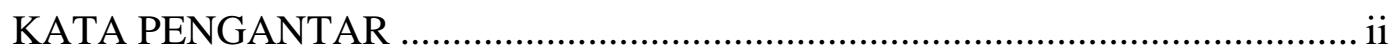

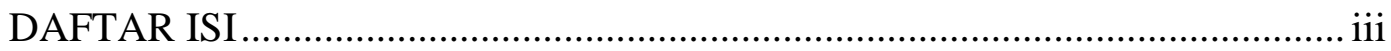

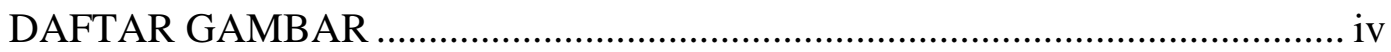

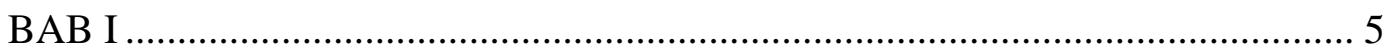

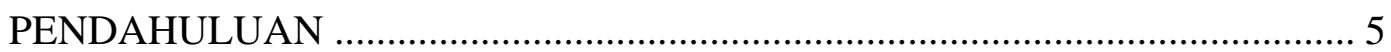

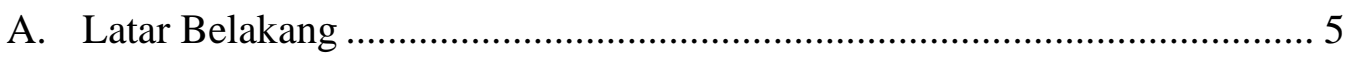

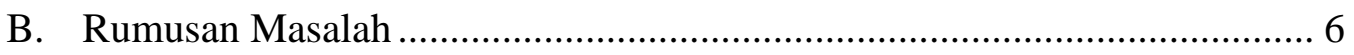

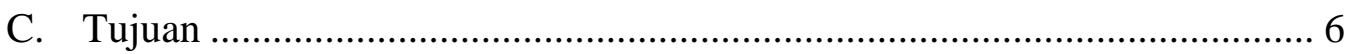

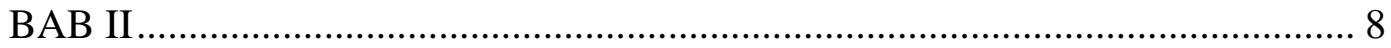

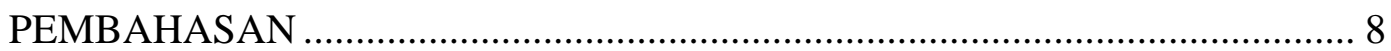

A. Definisi Pasar Persaingan Sempurna .......................................................... 8

B. Kurva Pasar Persaingan Sempurna .......................................................... 10

C. Efek Pengenaan Pajak Pada Pasar Persaingan Sempurna .......................... 14

D. Kelebihan dan Kekurangan Dari Pasar Persaingan Sempurna .................. 16

E. Pasar Persaingan Sempurna Dalam Persfektif Islam ............................... 20

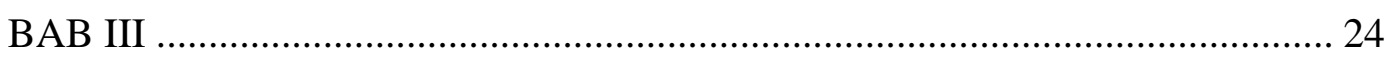

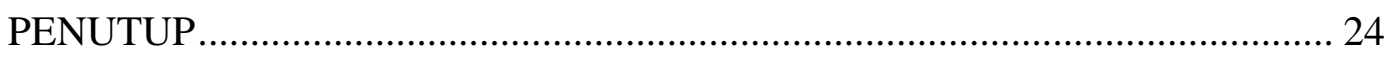

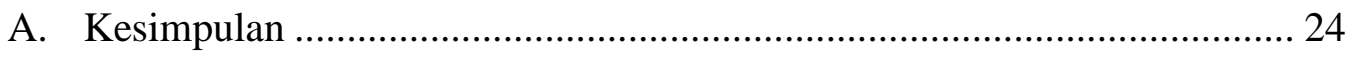

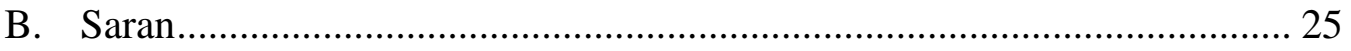

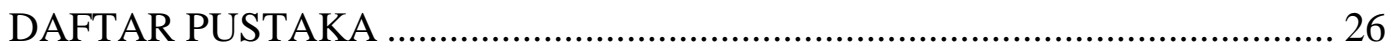




\section{DAFTAR GAMBAR}

Gambar 1: Kurva Permintaan Industri Perusahaan pada Pasar Persaingan

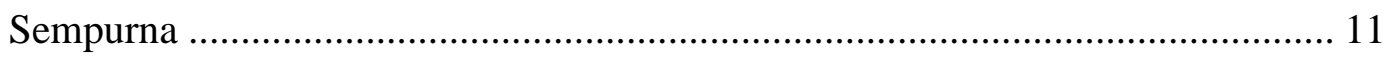

Gambar 2: Kurva Permintaan TR, AR, MR pada Pasar Persaingan Sempurna... 12

Gambar 3: Kondisi Ekuilibrium yang Digambarkan oleh Kurva TR dan TC ..... 13 Gambar 4: Kondisi Ekuilibrium Perusahaan yang Digambarkan Oleh Kurva MR dan MC 


\section{BAB I}

\section{PENDAHULUAN}

\section{A. Latar Belakang}

Apabila kita mendengar pasar tentu yang ada dipikiran kita adalah banyaknya penjual dan juga pembeli yang ada di tempat tersebut. Sehingga secara sederhana pasar dapat kita artikan sebagai suatu tempat di mana pembeli dan penjual bertemu untuk melakukan aktivitas jual beli barang ataupun jasa. Sedangkan pasar menurut istilah ekonomi dapat kita jelaskan bahwa pasar merupakan tempat bertemunya baik penujual maupun pembeli guna melakukan transaksi pembelian dan penjualan barang ataupun jasa, sehingga nanti tercipta harga keseimbangan sebagai harga yang berlaku di pasar saat itu dan juga dapat menetapkan jumlah yang nantinya diperdagangkan.

Dengan demikian dapat ditarik suatu kesimpulan bahwa pada setiap pertemuan atara penjual maupun pembeli akan terbentuk suatu harga keseimbangan sebagai harga yang disepakati antara pihak penjual dan juga pembeli. Seringkali kita melihat pasar yang ada di sekitar kita dalam bentuk pasar kongkret atau nyata bisa dilihat langsung oleh mata kita sendiri secara nyata. Misalnya pasar barang kebutuhan pokok. Semua aktivitas yang dilakukan di pasar pada dasarnya melibatkan dua pelaku utama, yaitu produsen dan juga konsumen. Keduanya memiliki peran yang besar terhadap pembentukan harga barang yang ada di pasar. 
Pada pembahasan ini kita hanya memfokuskan bahasan kita hanya pada satu konsep, yaitu pasar persaingan sempurna. Perlu kita pahami bersama bahwa suatu pasar persaingan sempurna merupakan suatu pasar yang sangat ideal dalam ekonomi. Hal ini dikarenakan pasar tersebut dianggap sebagai suatu pasar yang akan menjamin terwujudnya suatu kegiatan produksi baik barang ataupun jasa dengan optimal dan efisien.

\section{B. Rumusan Masalah}

Berdasarkan uraian pada latar belakang, maka rumusan masalah dalam makalah ini adalah sebagai berikut.

1. Apakah definisi dari pasar persaingan sempurna?

2. Bagaimana kurva dalam pasar persaingan sempurna?

3. Bagaimana efek pengenaan pajak pada pasar persaingan sempurna?

4. Apakah kelebihan dan kekurangan dari pasar persaingan sempurna?

5. Bagaimana pasar persaingan sempurna dalam persfektif islam?

\section{Tujuan}

Berdasarkan rumusan masalah yang telah disebutkan diatas, maka tujuan penulisan makalah ini adalah sebagai berikut.

1. Untuk mengetahui definisi pasar persaingan sempurna

2. Untuk mengetahui dan memahani kurva pasar persaingan sempurna

3. Untuk mengetahui dan memahami efek pengenaan pajak pada pasar persaingan sempurna

4. Untuk mengetahui kelebihan dan kekurangan dari pasar persaingan sempurna 
5. Untuk mengetahui dan memahami pasar persaingan sempurna dalam persfektif islam 


\section{BAB II}

\section{PEMBAHASAN}

\section{A. Definisi Pasar Persaingan Sempurna}

Pasar persaingan sempurna merupakan jenis pasar dimana tidak ada pelaku ekonomi yang mempunyai kekuasaan pasar (market power) terhadap harga suaru produk yang homogen. Pembeli maupun penjual tidak mempunyai kekuatan untuk empengaruhi harga pasar. Mereka hanya bertindak sebagai pengambil harga (price taker) dan bukan sebagai pembuat harga (price maker) ${ }^{1}$.

Pasar persaingan sempurna adalah suatu pasar dimana jumlah penjual dan pembeli (konsumen) sangat banyak dan produk atau barang yang ditawarkan sejeni atau serupa. Penjual yang harganya lebih tinggi tentu akan ditinggalkan pembeli. Hal inilah yang mendorong penjual untuk mengikuti saja harga yang berlaku di pasar (price taker) ${ }^{2}$. Contoh barang yang dijual pada bentuk pasar ini adalah beras, gandum, batu bara, kentang dan lain sebagainya. Pasar persaingan sempurna merupakan pasar dimana penjual dan pembeli tidak dapat mempengaruhi harga, sehingga harga di pasar benar-benar merupakan hasil kesepakatan dan interaksi antara penawaran dan permintaan.

\footnotetext{
${ }^{1}$ Hestie Nurhayati, "MAKALAH: PASAR PERSAINGAN SEMPURNA”, Academia.edu, 2018, academia.edu. https://www.academia.edu/37876248/MAKALAH_PASAR_PERSAINGAN_SEMPURNA_.

${ }^{2}$ Adiwarman A Karim, Ekonomi Mikro Islam (Jakarta: PT Rajagrafindo Persada, 2014), h. 195.
} 
Dalam pasar persaingan sempurna, harga dipengaruhi oleh permintaan, (demand) dan penawaran (suplay) antara penjual dan pembeli. Pembeli memberikan permintaan antara sifat barang yang akan dibeli, sedangkan penjual menawarkan nilai barang yang akan dijual. ${ }^{3}$ Pertukaran antara nilai keduanya adalah salah satu keseimbangan harga. ${ }^{4}$

Dalam pasar persaingan sempurna jumlah perusahaan sangat banyak dan kemampuan setiap perusahaan dianggap sedemikian kecilnya, sehingga tidak mempengaruhi pasar. Beberapa karakteristik agar pasar dapat dikatakan pasar persaingan sempurna yaitu ${ }^{5}$

a. Semua perusahaan memproduksi barang yang homogen (homogenitas product). Produk yang homogen adalah produk yang mampu memberi kepuasan (utilitas) kepada konsumen tanpa perlu mengetahui siapa produsennya.

b. Produsen dan konsumen memiliki pengetahuan atau informasi sempurna (perfect knowledge) tentang harga produk dan input yang dijual sehingga konsumen tidak akan mengalami perlakuan harga jual yang berbeda dari satu perusahaan dengan perusahaan lainnya.

${ }^{3}$ Supriadi, Skripsi: "Penetapan Standar Harga Jual Beli dalam Konsep Islam” (Makassar: UIN Alauddin Makassar, 2013), Hal. 3.

${ }^{4}$ Adiwarman A. Karim, Sejarah Pemikiran Ekonomi Islam (Jakarta: PT Raja Grafindo Persada, 2006), h. 358.

${ }^{5}$ Hestie Nurhayati, "MAKALAH: PASAR PERSAINGAN SEMPURNA", Academia.edu, 2018, academia.edu. https://www.academia.edu/37876248/MAKALAH_PASAR_PERSAINGAN_SEMPURNA_. 
c. Output sebuah perusahaan relative kecil dibanding output pasar (small relatively output).

d. Perusahaan menjual produknya dengan berpatokan pada harga yang ditentukan (price taker) pasar karena perusahaan tidak mampu mempengaruhi harga pasar.

e. Semua perusahaan bebas masuk dan keluar pasar (free entr and exit). Dalam pasar persaingan sempurna faktor mobilitasnya tidak terbatas dan tidak ada biaya yang harus dikeluarkan untuk memindahkan faktor produksi.

\section{B. Kurva Pasar Persaingan Sempurna}

Tingkat harga dalam pasar persaingan sempurna ditentukan oleh permintaan dan penawaran. Jumlah output perusahaan relative sangat kecil dibanding output pasar, maka berapapun yang dijual perusahaan, harga relative tidak berubah. ${ }^{6}$ Permintaan total (total revenue) perusahaan sama dengan jumlah output dikali harga jual. Karena ketidak mampuan penjual dan pembeli dalam mempengaruhi harga, maka harga secara otomatis telah ditentukan (given) oleh pasar. Dengan demikian permintaan rata-rata (average avenue) dan penerimaan marginal (marginal revenue) adalah sama dengan harga. Dengan demikian dapat digambarkan kurva permintaan dan penawaran sebagai berikut:

\footnotetext{
${ }^{6}$ Posma Sariguna Johnson Kennedy, "Modul Ekonomi Mikro Pasar Persaingan Sempurna", (Jakarta: FAKULTAS EKONOMI, UNIVERSITAS KRISTEN INDONESIA, 2021), Hal. 10-12.
} 


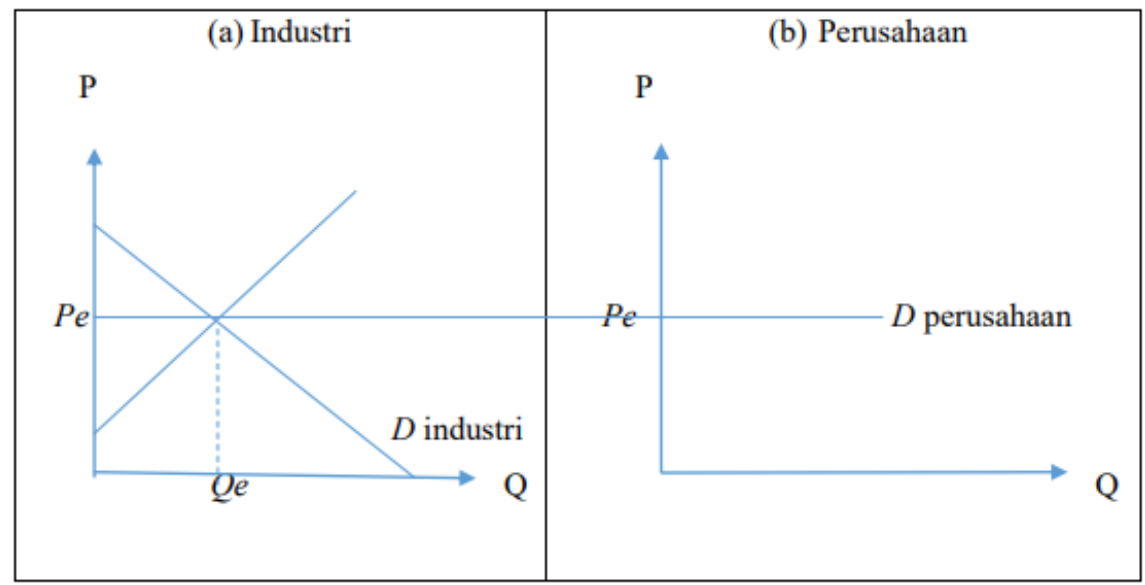

Gambar 1: Kurva Permintaan Industri Perusahaan pada Pasar Persaingan Sempurna

Keterangan gambar :

a. Pada kurva (a) industri, menunjukkan tingkat harga dalam pasar persaingan sempurna ditentukan oleh permintaan dan penawaran.

b. Pada kurva (b) Perusahaan, menunjukkan jumlah output perusahaan relatif sangat kecil dibanding output pasar, maka berapa pun yang dijual perusahaan, harga relatif tidak berubah.

c. Karena perusahaan individual bertindak sebagai price takers, maka kurva permintaan yang dihadapi oleh perusahaan berupa garis horisontal sebesar P.

d. Kurva permintaan (D) sama dengan kurva penarimaan rata-rata (AR) sama dengan kurva penerimaan marjinal (MR) dan sama dengan harga (P).

e. Kurva penerimaaan total berbentuk garis lurus dengan sudut kemiringan positif, bergerak mulai dari titik $(0,0)$. 


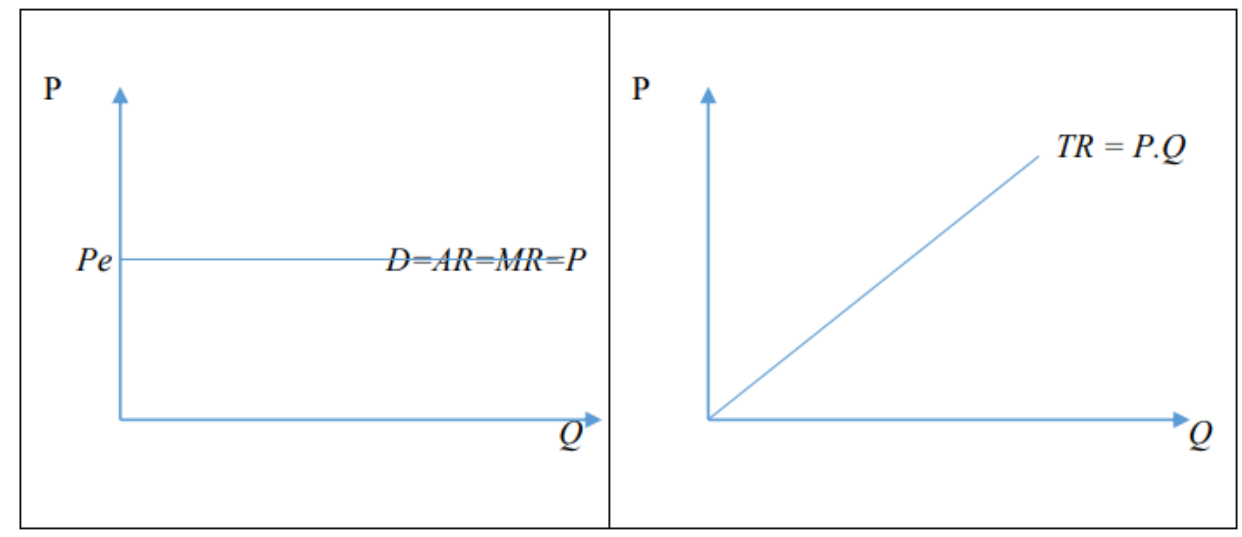

Gambar 2: Kurva Permintaan TR, AR, MR pada Pasar Persaingan Sempurna

1. Pemaksimuman Keuntungan pada Pasar Persaingan Sempurna

Perusahaan akan bekerja dalam situasi jangka pendek dan jangka panjang, dimana keduanya memiliki model pemaksimuman keuntungan (max profit) yang berbeda-beda. Analisis jangka pendek (shrot run), adalah dianggap setiap produsen tidak bisa menambah kapasitas pabriknya dan tidak mungkin bagi produsenprodusen baru masuk ke dalam pasar. Sedangkan analisis jangka panjang (long run) adalah di mana dimungkinkan adanya baik perluasan kapasitas pabrik oleh perusahaan-perusahaan yang telah ada maupun pembangunan pabrik-pabrik baru oleh pengusaha-pengusaha baru yang masuk ke pasar.

\section{Pemaksimuman Keuntungan pada Ekuilibrium}

Suatu perusahaan dalam kondisi ekuilibrium ketika ia mencapai keuntungan (profit, $\pi$ ) maksimum. Keuntungan $(\pi)$ adalah perbedaan atau selisih antara total cost (TC) dan total revenue (TR). Dengan demikian dapat dituliskan sebagai berikut: $\pi=$ TR - TC. Seperti telah dibahas pada bab sebelumnya, bahwa ekuilibrium perusahaan dalam asumsi pasar persaingan sempurna, secara grafis 
dapat ditunjukkan melalui dua pendekatan, yaitu : (1) Menggunakan kurva TR dan TC (2) Menggunakan kurva MR dan MC.

1. Ekuilibrium Perusahaan Menggunakan Kurva TR dan TC

Digambarkan posisi ekuilibrium perusahaan dengan menggunakan kurva TR dan TC dalam pasar persaingan sempurna. Kurva TR adalah suatu garis lurus melalui origin, yang menunjukkan bahwa harga output adalah konstan pada semua tingkat output. Produsen akan selalu menerima harga atau price taker dan dapat menjual setiap outputnya pada harga pasar yang berlaku dengan TR yang naik secara proporsional dengan volume penjualannya. Slope kurva TR adalah marginal revenue (MR). MR ini konstan dan sama dengan harga pasar (P), karena semua unit output dijual pada harga yang sama. Dengan demikian secara matematis dapat dituliskan :

$$
\mathrm{MR}=\mathrm{AR}=\mathrm{P}=\mathrm{P}_{\text {ekuilibrium }}
$$

Perusahaan mencapai keuntungan maksimum pada penjualan output ekuilibrium, di mana jarak vertikal antara kurvr TR dan kurva TC paling lebar.

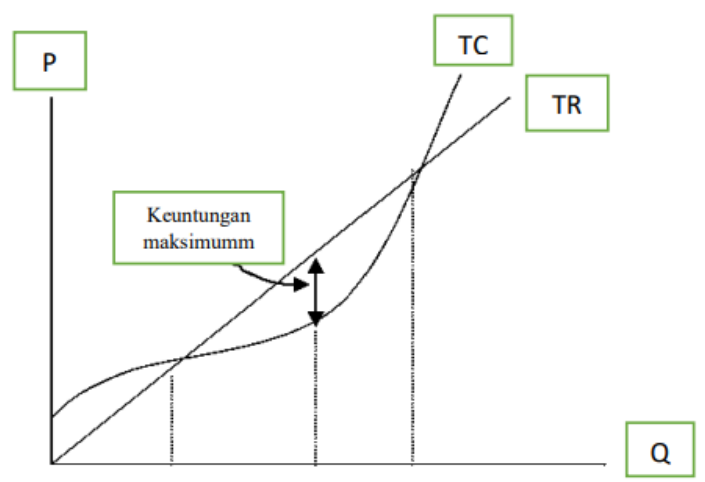

Gambar 3: Kondisi Ekuilibrium yang Digambarkan oleh Kurva TR dan TC 
2. Ekuilibrium Perusahaan Menggunakan Kurva MR dan MC

Maksimisasi keuntungan atau profit dapat dijelaskan juga menggunakan kriteria marginal revenue sama dengan marginal cost (atau MR=MC). Karena MR untuk perusahaan pada pasar persaingan sempurna adalah $\mathrm{P}$, maka output optimal dihasilkan jika $\mathrm{P}=\mathrm{MC}$. Seperti pada gambar di output optimal untuk pasar persaingan sempurna jangka pendek di bawah ini:

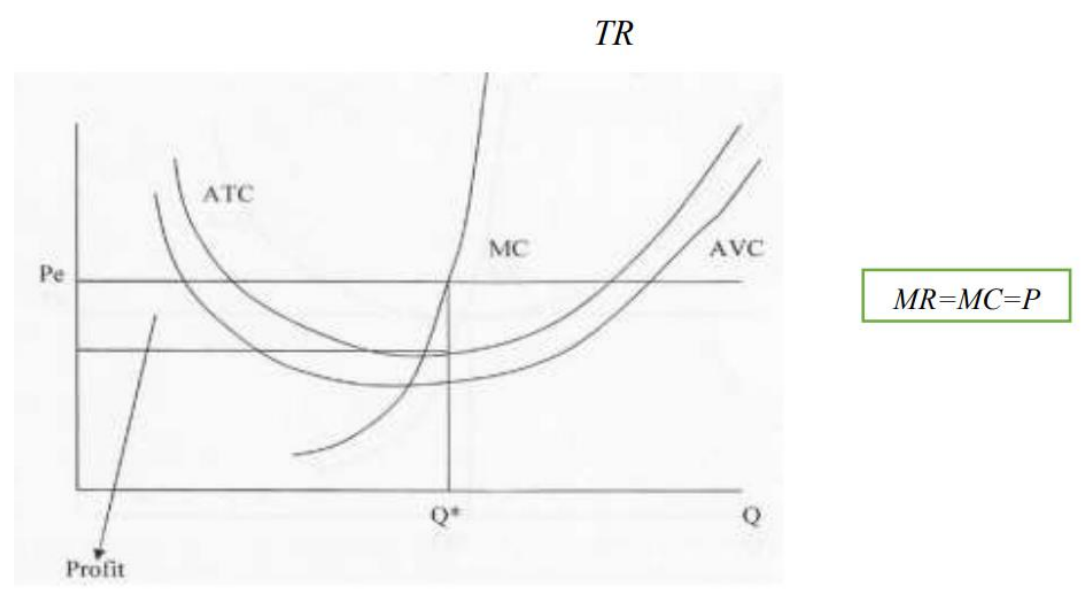

Gambar 4: Kondisi Ekuilibrium Perusahaan yang Digambarkan Oleh Kurva MR dan MC

\section{Efek Pengenaan Pajak Pada Pasar Persaingan Sempurna}

Para ahli ekonomi neo-klasik umumnya menyepakati, bahwa pajak perseroan akan dikenakan pada keuntungan perseroan. Oleh karena itu, pajak tersebut tidak akan berpengaruh terhadap struktur biaya produksi. Suatu perseroan yang didirikan dengan tujuan mencapai keuntungan maksimal, tidak akan berusaha untuk menggeserkan pajak perseroannya kepada pihak lain. Alasannya, sebuah perusahaan yang bertujuan mendapatkan keuntungan maksimal akan berproduksi pada tingkat di mana penerimaan marginal (MR, marginal revenue) sama dengan 
biaya marginal (MC, marginal cost $)^{7}$. Pajak perseroan dikenakan pada keuntungan perseroan, sehingga tidak mempengaruhi struktur biaya internal perusahaan. Pada dasarnya, semua perusahaan yang menghadapi struktur pasar persaingan sempurna, dalam jangka panjang akan memperoleh keuntungan normal, yaitu ketika biaya total (TC, total cost) sama dengan penerimaan total (TR, total revenue), sehingga keuntungan sama dengan nol. Dalam keadaan ini, maka tidak ada satu pun perusahaan yang berkewajiban membayar pajak perseroan. Sedangkan dalam jangka pendek, seperti diketahui, memang ada perusahaan yang memperoleh keuntungan dan ada perusahaan yang menderita kerugian. Tetapi dalam jangka panjang, keadaan timpang ini akan diseimbangkan, ketika perusahaan yang mendapat keuntungan disaingi secara ketat oleh perusahaan lainnya. Karena demikian ketatnya persaingan (perfect competition), maka akhirnya tingkat keuntungan semua perusahaan menjadi sama-sarna nol $(\mathrm{TR}=\mathrm{TC})$.

Penetapan pajak adapat dibagi atas dua, yaitu pajak lump sum dan pajak spesifik. Kedua jenis penetapan pajak ini akan menghasilkan efek yang berbeda. Pajak lump sum adalah pajak yang dikenakan sebesar jumlah tertentu berapapun jumlah output yang diproduksi dan dijual. Penetapan pajak ini dapat mengurangi atau bahkan menghilangkan keuntungan monopolis tanpa mempengaruhi harga dan output. Pajak lump sum merupakan biaya tetap bagi perusahaan, sehingga hanya

${ }^{7}$ Sigit Sardjono, "MASALAH PENGENAAN PAJAK DAN UPAYA MENGHINDARI DITINJAU DARI TEORI EKONOMI MIKRO". DIE - Jurnal Ilmu Ekonomi dan Manajemen. Vol 5 No. 4 , 2019, Hal. 69-103 
akan mempengaruhi kurva biaya rata-rata, yaitu bergeser keatas sedangkan kurva biaya marginal dalah tetap.

Pajak spesifik adalah pajak yang dikenakan per unit output. Pajak ini merupakan biaya variable bagi pasar monopolos, dengan demikian akan mempengaruhi kurva biaya rata-rata dan kurva biaya marginal, yaitu bergeser ke kanan atas.

\section{Kelebihan dan Kekurangan Dari Pasar Persaingan Sempurna}

Karena kondisinya dengan asumsi yang sempurna, di dalam struktur pasar persaingan sempurna akan selalu terwujud efisiensi. Efisiensi yang dikenal ada dua jenis, yaitu efisiensi produktif dan efisiensi alokatif, yang akan dijelaskan berikut ini $^{8}$ :

\section{Efisiensi produktif}

Untuk mencapai efisiensi produktif harus dipenuhi dua syarat. Syarat pertama adalah untuk setiap tingkat produksi, biaya yang dikeluarkan adalah yang paling minimum. Untuk menghasilkan suatu tingkat produksi berbagai gabungan faktor-faktor produksi, yang paling efisien adalah gabungan yang mengeluarkan biaya paling sedikit. Syarat ini harus dipenuhi pada setiap tingkat produksi. Syarat yang kedua adalah industri secara keseluruhan harus memproduksi barang pada

${ }^{8}$ Posma Sariguna Johnson Kennedy, "Modul Ekonomi Mikro Pasar Persaingan Sempurna", (Jakarta: FAKULTAS EKONOMI, UNIVERSITAS KRISTEN INDONESIA, 2021), Hal. 14-16. 
biaya rata-rata yang paling rendah, yaitu pada waktu kurva $\mathrm{AC}$ mencapai titik yang paling rendah. Apabila suatu industri mencapai keadaan tersebut maka tingkat produksinya dikatakan mencapai tingkat efisiensi produksi yang optimal, dan biaya produksi yang paling minimal.

\section{Efisiensi Alokatif}

Alokasi sumber-sumber daya mencapai efisiensi yang maksimum apabila dipenuhi syarat berikut : harga setiap barang sama dengan biaya marjinal untuk memproduksi barang tersebut. Berarti untuk setiap kegiatan ekonomi, produksi harus terus dilakukan sehingga tercapai keadaan dimana harga=biaya marjinal. Dengan cara ini produksi berbagai macam barang dalam perekonomian akan memaksimumkan kesejahteraan masyarakat.

Beberapa kebaikan dari pasar persaingan sempurna dibandingkan bentuk/struktur pasar-pasar yang lain adalah:

1. Persaingan sempurna memaksimumkan efisiensi

Pada struktur pasar persaingan sempurna, dalam jangka panjang perusahaan akan mendapat untung normal (normal profit). Keuntung normal ini akan dicapai apabila biaya produksi adalah yang paling minimum. Dengan demikian dalam jangka panjang efisiensi produktif selalu dicapai oleh perushaan dalam persaingan sempurna. Selain itu dalam persaingan sempurna harga $=$ hasil penjualan marjinal. Dalam melakukan pemaksimuman keuntungan syaratnya adalah hasil penjualan marjinal = biaya marjinal. Dalam jangka panjang keadaan ini juga berlaku, yaitu harga 
= hasil penjualan marjinal = biaya marjinal. Kesamaan ini membuktikan bahwa pasar persaingan sempurna juga mencapai efisiensi alokatif. Dengan demikian efisiensi produktif dan efisiensi alokatif dapat dicapai dalam pasar persaingan sempurna.

2. Adanya kebebasan untuk memilih (choice)

Didalam pasar yang bebas seperti yang terjadi pada struktur pasar persaingan sempurna, tidak seorang pun mempunyai kekuasaan dalam menentukan harga, jumlah produksi dan jenis barang yang diproduksikan. Begitu pula dalam menentukan bagaimana faktor-faktor produksi digunakan dalam masyarakat, efisiensilah yang menjadi faktor yang menentukan pengalokasinya. Dengan adanya kebebasaan untuk memproduksikan berbagai jenis barang, maka masyarakat juga dapat mempunyai pilihan yang lebih banyak terhadap barang-barang dan jasa-jasa yang diperlukan untuk memenuhi kebutuhannya. Masyarakat mempunyai kebebasan yang penuh atas pilihan yang akan dibuatnya dalam menggunakan faktor-faktor produksi yang mereka miliki.

Disamping memiliki kebaikan-kebaikan, pasar persaingan sempurna juga memiliki keburukan-keburukan antara lain:

1. Persaingan sempurna tidak mendorong inovasi

Dalam pasar persaingan sempurna teknologi dapat dicontoh dengan mudahnya oleh perusahaan lain, sehingga tidak ada insentif bagi perusahaan untuk mengembangkan teknologi dan teknik memproduksi yang baru. Oleh 
sebab itulah keuntungan dalam jangka panjang hanyalah berupa keuntungan normal (normal profit), karena walaupun pada awalnya perusahaan dapat menaikkan efisiensi dan menurunkan biaya, namun perusahaan-perusahaan lain dalam waktu singkat juga berbuat yang sama. Ketidakkekalan keuntungan dari mengembangkan teknologi ini menyebabkan perusahaanperusahaan tidak terdorong untuk melakukan perkembangan teknologi dan inovasi. Selain itu juga, perusahaan-perusahan yang terdapat pada struktur pasar persaingan sempurna biasanya kecil ukurannya, sehingga tidak mampu membuat penelitian untuk mengembangkan teknologi yang lebih baik karena sangat mahal biayanya.

2. Persaingan sempurna adakalanya menimbulkan biaya sosial. Ditinjau dari sudut pandangnan perusahaan, penggunaan sumber daya mungkin sangat efisien. Namun ditinjau dari sudut kepentingan masyarakat, adakalanya merugikan. Contohnya dengan adanya pencemaran, dan sebagainya.

3. Membatasi pilihan konsumen. Karena barang yang dihasilkan perusahaanperusahan adalah sama semua, konsumen mempunyai pilihan yang terbatas untuk menentukan barang yang akan dikonsumsinya.

4. Biaya dalam pasar persaingan sempurna mungkin lebih tinggi. Dikatakan biaya produksi dalam pasar persaingan sempurna adalah paling minimum. Namun dapat saja ini tidak selalu benar, karena mungkin saja perusahaanperusahaan di struktur pasar lainnya mungkin dapat mengurangi biaya produksi sebagai akibat menikmati skala ekonomi, perkembangan teknologi dan inovasi. 
5. Distribusi pendapatan tidak selalu rata. Pola permintaan akan menentukan bentuk pengalokasian sumber-sumber daya. Ini berarti distribusi pendapatan menentukan bagaimana bentuk dari penggunaan sumbersumber daya yang efisien. Jika distribusi pendapatan tidak merata maka penggunaan sumber-sumber daya (yang dialokasikan secara efisien) dapat saja akan lebih banyak digunakan untuk kepentingan golongan kaya.

\section{E. Pasar Persaingan Sempurna Dalam Persfektif Islam}

Dalam Islam, umat muslim itu dianjurkan untuk berusaha apa saja selama masih dalam koridor syariah, artinya selama usaha itu tidak melanggar ketentuan-ketentuan yang di syariatkan Allah SWT. Demikian pula dalam hal melakukan kegiatan ekonomi, semua boleh dilakukan asalkan tidak melanggar aturan-aturan tersebut. Salah satu aktivitas ekonomi dapat terlihat dalam pasar, dimana bertemunya antara penjual dan pembeli untuk melakukan transaksi atas barang atau jasa, baik dalam bentuk produksi maupun penentuan harga. Transaksi jual beli dibolehkan dalam Islam selama tidak mengandung riba dan hal-hal yang dapat merugikan salah satu pihak ${ }^{9}$, sebagaimana Allah SWT berfiman dalam QS. Al-Baqarah ayat 275:20 yang artinya:

"Yang demikian itu karena mereka berkata bahwa jual beli itu sama dengan riba. Padahal Allah telah menghalalkan jual beli dan mengharamkan riba."

\footnotetext{
${ }^{9}$ Ahmad Afan Zaini, "PASAR PERSAINGAN SEMPURNA DALAM PERSFEKTIF EKONOMI ISLAM." Jurnal Ummul Qura. Vol. 4 No.2, 2014, Hal. 98-99.
} 
Mekanisme pasar yang Islami menurut Ibnu Taimiyah haruslah memiliki kriteria-kriteria berikut:

1. Orang-orang harus bebas untuk masuk dan keluar pasar. Memaksa penduduk menjual barang tanpa ada kewajiban untuk menjualnya adalah tindakan yang tidak adil dan ketidakadilan itu dilarang.

2. Tingkat informasi yang cukup mengenai kekuatan-kekuatan pasar dan barang-barang dagangan adalah perlu.

3. Unsur-unsur monopolistik harus dilenyapkan dari pasar sehingga segala bentuk kolusi antara kelompok para penjual dan pembeli tidak diperbolehkan.

4. Homogenitas dan standardisasi produk sangat dianjurkan ketika terjadi pemalsuan produk, penipuan dan kecurangan-kecurangan dalam mempresentasikan barang-barang tersebut.

Setiap penyimpangan dari kebebasan ekonomi yang jujur, seperti sumpah palsu, penimbangan yang tidak tepat, dikecam oleh ajaran Islam.

Dari pendapat Ibnu Taimiyah di atas tentang mekanisme pasar dalam Islam, kita dapat melihat mekanisme-mekanisme tersebut mengarah pada karakteristik pasar persaingan sempurna. Hal itu berarti bahwa pasar dalam Islam itulah yang dalam teori konvensional disebut dengan pasar persaingan sempurna, dimana 
asumsi-asumsi yang disebutkan oleh pakar ekonomi konvensional ada (ditemukan) dalam pasar yang Islami $^{10}$.

Salah satu contoh pasar persaingan sempurna dalam pasar Islam adalah yang terjadi pada masa khalifah Umar bin Khattab RA. Pada saat itu Umar berjalan dipasar kurma, ketika itu Umar mendapati salah seorang pedagang yang menjual dibawah harga yang ada di pasar tersebut. Umar memberikan dua pilihan pada penjual tersebut, yang pertama naikkan harga sampai sama dengan harga yang ada di pasaran atau keluar dari pasar ini.

Kisah di atas dapat ditarik kesimpulan bahwa dalam sebuah pasar persaingan sempurna harga yang ditawarkan adalah sama dengan harga yang ditawarkan oleh seluruh pedagang dalam pasar tersebut jika barang dagangan tidak terdeferensiasi (berbeda).

Masih menurut Ibnu Taimiyah bahwa penetapan harga menjadi penting atau diperlukan untuk mencegah manusia (produsen) menjual makanan dan barang lain hanya kepada kelompok tertentu dengan harga ditetapkan sesuka hati.

Ini merupakan kezaliman di muka bumi, demi tercapainya kemaslahatan wajib diterapkan penetapan harga. "Sesungguhnya kemaslahatan manusia

\footnotetext{
${ }^{10}$ Ahmad Afan Zaini, "PASAR PERSAINGAN SEMPURNA DALAM PERSFEKTIF EKONOMI ISLAM." Jurnal Ummul Qura. Vol. 4 No.2, 2014, Hal. 100.
} 
belum sempurna kecuali dengan penetapan harga. Yang demikian itu perlu dan wajib diterapkan secara adil dan bijaksana," kata Ibnu Taimiyah ${ }^{11}$.

${ }^{11}$ Yusuf Qardhawi, Norma dan Etika Ekonomi Islam (Jakarta: Gema Insan Press, 1997) 


\section{BAB III}

\section{PENUTUP}

\section{A. Kesimpulan}

1. Pasar persaingan sempurna adalah suatu pasar dimana jumlah penjual dan pembeli (konsumen) sangat banyak dan produk atau barang yang ditawarkan sejeni atau serupa. Dalam pasar persaingan sempurna jumlah perusahaan sangat banyak dan kemampuan setiap perusahaan dianggap sedemikian kecilnya, sehingga tidak mempengaruhi pasar.

2. Tingkat harga dalam pasar persaingan sempurna ditentukan oleh permintaan dan penawaran. Jumlah output perusahaan relative sangat kecil dibanding output pasar, maka berapapun yang dijual perusahaan, harga relative tidak berubah.

3. Penetapan pajak adapat dibagi atas dua, yaitu pajak lump sum dan pajak spesifik. Kedua jenis penetapan pajak ini akan menghasilkan efek yang berbeda. Pajak lump sum merupakan biaya tetap bagi perusahaan, sehingga hanya akan mempengaruhi kurva biaya rata-rata, yaitu bergeser keatas sedangkan kurva biaya marginal dalah tetap. Sedangkan pajak spesifik adalah pajak yang dikenakan per unit output. Pajak ini merupakan biaya variable bagi pasar monopolos, dengan demikian akan mempengaruhi kurva biaya rata-rata dan kurva biaya marginal, yaitu bergeser ke kanan atas.

4. Kelebihan dari pasar persaingan sempurna adalah persaingan sempurna memaksimumkan efisiensi dan adanya kebebasan untuk memilih (choice) 
sedangkan kekurangannya yaitu persaingan sempurna tidak mendorong inovasi, persaingan sempurna adakalanya menimbulkan biaya sosial, membatasi pilihan konsumen, biaya dalam pasar persaingan sempurna mungkin lebih tinggi, distribusi pendapatan tidak selalu rata.

\section{B. Saran}

Diharapkan dengan berbagai bentuk yang terjadi dalam persaingan pasar, akan semakin memajukan perekonomian Indonesia dan membangkitkan semangat dalam melakukan berbagai kegiatan usaha dalam berbagai bentuk untuk mewujudkan semangat dalam melakukan berbagai bentuk untuk mewujudkan Indonesia sebagai negara yang memiliki ekonomi yang kuat dan menjadi mitra dalam persaingan pasar dan duna usaha secara global. 


\section{DAFTAR PUSTAKA}

Karim, A. (2014). Ekonomi Mikro Islam. Jakarta: PT Rajagrafindo Persada.

Kennedy, P. S. (2018). Modul Ekonomi Mikro Pasar Persaingan Sempurna. UNIVERSITAS KRISTEN INDONESIA, FAKULTAS EKONOMI, Jakarta. Retrieved 11 02, 2021

Nurhayati, H. (2018). Retrieved from academia.edu: https://www.academia.edu/37876248/MAKALAH_PASAR_PERSAINGAN_SE MPURNA_

Qardhawi, Y. (1997). Norma dan Etika Ekonomi Islam. Jakarta: Gema Insan Press.

Rizky, N. (2020). STRUKTUR PASAR PERSAINGAN SEMPURNA. Retrieved 11 03, 2021, from eprints.umsida.ac.id: http://eprints.umsida.ac.id/id/eprint/6996

Sardjono, S. (2009). MASALAH PENGENAAN PAJAK DAN UPAYA MENGHINDARI DITINJAU DARI TEORI EKONOMI MIKRO. DIE - Jurnal Ilmu Ekonomi dan Manajemen, 5(4), 69-103.

Supriadi, S. (2013). Penetapan Standar Harga Jual Beli dalam Konsep Islam (Doctoral dissertation, UIN Alauddin Makassar).

Zaini, A. A. (2014). PASAR PERSAINGAN SEMPURNA DALAM PERSFEKTIF EKONOMI ISLAM. Jurnal Ummul Qura, IV(4), 88-104. 